\title{
Songs of the King's Wives: Women, Power and Performance in the Yoruba Public Sphere
}

\author{
Bode Omojola*
}

\begin{abstract}
Indigenous festivals, which rely significantly on music and dance, often constitute the village public sphere and the social arena within which the structures of power are performed and negotiated in traditional African communities. This article discusses two unique musical traditions which feature prominently at annual traditional festivals in Emure-Ekiti, a Yoruba town in Western Nigeria. The musical traditions are orin olori (songs of the king's wives) and a related ensemble, orin airegbe, a musical tradition associated with female chiefs. Exploring an ethnomusicological approach, this article argues that the complementary relationship between these two all-female musical traditions and the scope of their performance practices draw attention to the ways in which public performance speaks to the status and agency of women in traditional Yoruba societies.
\end{abstract}

\section{Résumé}

Les festivals indigènes, qui dépendent de façon significative de la musique et la danse, constituent souvent la sphère publique du village et l'arène sociale au sein desquelles les structures du pouvoir sont exécutées et négociées dans des communautés africaines. Cet article traite de deux traditions musicales uniques qui se mettent en évidence aux festivals traditionnels d'Emure-Ekiti, une ville Yoruba à l'Ouest du Nigeria. Les traditions musicales sont Orin olori (chants des épouses du roi) et un ensemble apparenté, Orin airegbe, une tradition musicale associée aux femmes chefs. En explorant une approche ethnomusicologique, je soutiens que la relation de complémentarité entre ces deux traditions musicales entièrement féminines et la portée de leurs interprétations attirent l'attention sur la manière dont l'interprétation publique témoigne du statut et du rôle de la femme dans les sociétés traditionnelles Yoruba.

* Mount Holyoke College, South Hadley, MA, USA.

E-mail: bomojola@mtholyoke.edu. 


\section{Introduction}

Historical and oral sources point to the vibrancy of musical ensembles as an integral part of palace protocol in ancient Yoruba palaces. The functions of such ensembles include routine activities like saluting the king and royal dignitaries as well as announcing the imminent arrival of visitors. Although many palace ensembles have dwindled in size today they remain a visible and an important aspect of court ceremonies. In palaces such as those of the Alaafin of Oyo and the Ataoja of Oshogbo, for example, talking drummers and bugle players continue to function on a daily basis. Such ensembles, though often limited to just a few instruments on ordinary days, are usually augmented by musicians from outside the palace to provide a performance that is befitting of special occasions.

This paper discusses two unique types of palace-affiliated musical ensembles in Emure, a small Yoruba town in the Ekiti region in south-western Nigeria. These are orin olori (songs of the king's wives) and its related ensemble, orin airegbe, a musical performance that is associated with female chiefs as well as puberty rites. Membership of orin olori ensemble is exclusive to the wives of the reigning king, and widows of departed ones. Although quite widespread in Ekiti, this type of ensemble is rare in other parts of Yoruba land, a phenomenon that draws attention to the ways in which cultural practices in Ekiti tend to differ significantly from those of the more urban parts of Yorubaland. Orin olori maintains a complementary relationship with ere airegbe (airegbe performance). Ere airegbe, though originally performed by Emure women during the annual initiation ceremony for pubescent girls, is now performed mainly by female chiefs and no longer restricted to its original context. In analyzing olori and airegbe performances in this article, I am guided by certain critical questions as posed by Drewal (1992:172). According to her, in order to move beyond a 'social Darwinist' perspective on gender, it is necessary to ask whether 'the construction of gender in African performances is always in fact asymmetrical and whether power always resides in the male half of that structure'. I am also interested in exploring how orin olori and airegbe relate to certain well known conventions of Yoruba musical practice. I argue that the complementary relationship between the two ensembles and the scope of the creative and performance strategies associated with them highlight important perspectives regarding the ways in which public musical performances speak to the status and agency of women in Emure-Ekiti. As a background to my discussion it is instructive briefly to evaluate the relationship between gender and public performance in Africa. 


\section{Gender in African Performance}

Sex- and gender-related issues are often critical to the conception and organization of African musical ensembles. The intersection of gender and power in African societies often manifests itself vividly in bounded, formal performances. Drewal (1992:172) has observed for example that 'there are more restrictions placed on women in performances organized by men than there seem to be in women's performances'. Citing examples from Yoruba media art to further support this view, she explains that socially inscribed notions of gender are manifest both in the type of materials that men and women may work with as well as in the types of artistic formations those artists may create. For example, 'while women work in clay, men specialize in wood, metal and beads’ (Drewal 1992:172).

Perceived as masters of the private domain, African women are often associated with informal and non-professional performances. This is a cultural practice that has been discussed by various scholars working in different parts of the continent. In her discussion of Hausa Muslim women's performances, Mack (2004:4) has, for example, explained that although exceptionally gifted Hausa women in Kano may have the opportunity to perform in public spaces such as an emir's palace, the practice of wife seclusion and the need for women to fulfil their responsibilities as mothers and wives in a predominantly Islamic environment often dictate that they perform mainly in private spaces located in the harems of their husbands and inside family compounds. A comparative, though contextually different situation exists among the women of the KwaZulu iBandla lamaNazaretha (Nazareth Baptist Church), where, as Muller (1999:224-226) has explained, female performances, even within the context of a modern, syncretic religious organization, are restricted largely to the private homes of individuals and to meetings that are exclusive to women. These examples reflect a general tendency for African musical performances to be dominated by men at the professional and public sphere level. In many such situations women often complement male performances rather peripherally as creators of ululations and as cheerers. Men often dominate instrumental ensembles as has been documented in a number of examples, including dundun (Euba 1990; Yoruba Nigeria); agbekor (Locke 2005; Ewe, Ghana); sabar (Tang 2007; Wolof, Senegal); and baakisimba (Nannyonga-Tamusuza 2005; Buganda, Uganda). Nannyonga-Tamusuza (2005:17), narrating her experience with reference to baakisimba, for example, has stated that 'roles ... were clearly distinguished; boys were restricted to drumming and girls controlled the dancing arena. Whenever I tried to "beat" the drums, my teachers outwardly told me "women do not beat the drums, they are dancers"'. 
It is important to observe that although these prominent examples all point in the direction of a pre-determined social hierarchy within which women are perpetually disadvantaged, other examples, such as those that I examine in this paper, point in the direction of a dialectical framework within which life and play reshape one another, and therefore within which issues such as those relating to gender are debated and contested. The processual nature of African performances, defined in the ways in which they construct and re-invent themselves, speaks to the utility of an agency-driven musical medium that facilitates social conversation as well as the questioning and the negotiation of social relations. Drewal has thus also observed that African performances or rituals 'operate not merely as models of and for society, which somehow stand timelessly alongside "real” life. Rather, they construct what reality is and how it is experienced and understood' (Drewal 1992:174). My discussion of the music of Emure women examines the ways in which song-texts, musical instrumentation (or the lack of it), the processes of musical composition and performance, are structured and deployed to draw attention to the status and agency of women in Yoruba culture and to their roles as social actors and active moulders of the public sphere.

\section{Olori and Airegbe Ensembles}

Olori ensemble in Emure consists mainly of singers who also dance, and two instrumentalists, each playing an agere drum, a single-headed membranophone. Olori singing is cast in a cantor-chorus format in which the role of cantor moves rather freely amongst a core group of leaders. The two female drummers, whose roles include setting the tempo and sustaining a pervading element of dance, do not belong to the traditional Yoruba drumming families. Their status as drummers thus challenges and deviates from the more conventional Yoruba belief that drummers must belong to endogamous hereditary drumming families known as ayan. One of the two women informed me, for example, that she had no prior musical experience before joining olori ensemble and that she perfected her drumming skills through regular practice and by performing regularly as a member of olori ensemble.

The most important context for the public performance of olori ensemble is the annual new yam festival (odun isu titun) which takes place in July or August. The festival is noted for the symbolic tasting of the yam by the king, marking the official declaration of the beginning of the harvest season. The festival, like similar ones all over Yorubaland, provides an opportunity for members of the Emure community to celebrate their common ancestry, pay homage and re-affirm their loyalty to the king.

Airegbe was originally restricted to the initiation ceremony for pubescent girls. Significantly however, new musical compositions that derive from the 
original airegbe tradition are now often performed mainly by Emure female chieftaincy title holders on a wide range of occasions that include the installation of a new king, the commissioning of a new palace, and investiture ceremonies for newly appointed chiefs. While olori music is performed to the accompaniment of agere drums, airegbe does not make use of musical instruments. But although, airegbe and olori are two distinct categories, a complementary relationship exists between them since many of the women who perform airegbe are also members of the olori ensemble because of their dual status as chiefs and royal wives. While the membership of olori ensemble attracts mostly young adults and a few elderly people, virtually all members of airegbe ensemble are advanced in age. Members of olori who become chiefs automatically become members of airegbe while retaining their membership of olori. It is also important to note that performances of airegbe and olori now often take place at the same event, especially during important festivals and special occasions involving the entire Emure community.

\section{Regency, Gender and Social Mobility in Performance}

The social significance of these two ensembles was vividly demonstrated during a performance event that I watched in 2007 when I visited Emure Ekiti. The event, which started as olori performance, later evolved into airegbe in a manner that symbolically reflected the complementary relationship between the two groups. The ceremony took place when the town was under the administration of a female regent, an interim leader, who had been chosen through divination (ifa) to act as ruler until the selection of a new king. The death of a king usually calls for the appointment of a female regent in Ekiti towns, providing a rare opportunity for a female to lead in a time often marked by instability as different families and individuals compete (even fight one another) to occupy the throne. The festival was thus unique in the sense that women played an even greater role due to the fact that a female ruler had to preside over a festival known to be dominated by women.

The festival began with a special performance of olori songs, distinguished by the use of agere drums and the singing of specific songs. After about forty-five minutes, the performance shifted to airegbe performance notably through the cessation of agere drumming and the singing of a new set of songs. At this point, members of olori who were not chiefs withdrew from the performance. The presiding female regent was clad in male attire, wearing neck-beads and holding a horsetail, two important emblems of Yoruba royal authority. To show her appreciation, she periodically got up from her seat to dance and to paste wads of money on the foreheads of the dancing chiefs who, in return, praised her and wished her a successful tenure. 
The songs performed at this festival generally emphasized the critical role of women in the community while affirming the supremacy of the political authority of the Elemure. In the song titled 'Opo Ule Elemure' (Pillars of Elemure's Palace), for example, the women emphasized the importance of the local market as a locus of economic activity and suggested that women are the economic managers of the market:

Opo Ule Elemure (Pillars of Elemure's Place)

1. Opo ule elemure o,

Pillars of the palace of Elemure

2. Ara ule olaja lore,

The dwellers of the market place

3.Opo momo yo'se labe orisha,

The pillar must not collapse under the gods

4. Maa se t'emiye l'oju aseni

We will succeed in spite of our detractors.

As instruments of social stability and cohesion, their role is comparable to the concrete pillars of the king's palace. In another song, 'Aso Uyi' (Costume of Honour), the women pledge their allegiance to their king by enjoining all Emure women to answer his call to duty:

Aso Uyi (Wrapper of Honour)

1. Aso uyi ni in muro o,

We are knotting a wrapper of honour

2. Ua uyi ni in wo,

The sight of us is a sight of honour

3. Owa ran ni ya pe a o,

The king has sent for us

4. Ara oye wo mo sere.

Thank you for the honour.

They sing that their presence and their performance activities (ua) are shaped in response to the king's call, and express their gratitude to the king for counting them worthy of serving their community. They explain that they are persons of honour, affirming that they 'knot a wrapper of honour'.

\section{'You Caught Us Unawares': Agency and Dialogue in the Creative Process}

Like the performance and the song-texts described above, the creative process through which Emure female performers generate their music resonates with considerable social significance and therefore deserves analytical attention. Ethnomusicologists working in Africa often focus mainly on public 
performances while largely ignoring the creative process that leads to them. Commenting on the relative lack of scholarly attention to the creative process in African music, Ampene, in his study of Nnwonkoro, a song tradition of the Akan women of Ghana, has observed that 'not much is known about the techniques and processes of musical composition in preliterate societies' (Ampene 2005:11). Although it is true that the scene of public performance constitutes a major avenue for creative engagement with the material of performance ('composition-in-performance', Ampene 2005:8), a much more deliberative process of creativity often precedes and generates the actual performance. As Merriam (1960:165-84 in Ampene 2005:11) has observed, for example, African musicians do practice 'composition, recognize it as a distinct process, and are in a number of cases quite able to discuss it'. But while some African musicians may not always be disposed to describing the nature of the creative process they engage in, that process is nonetheless often rigorous and intensive as I have found out in my study of the music of Emure women. The ethnographic description below captures the dynamics of this process as it occurred during one of my many visits to Emure to study airegbe performance.

My first contact with the women who performed airegbe was in 2006 when I embarked on a preliminary investigation. I had become fascinated with their performance after watching a video recording of a previous edition of the initiation festival for pubescent girls. In 2007, when I travelled back to observe that year's edition of the festival, I realized that many of the songs that were performed during that festival were different from those on the video recording. This made me to doubt the authenticity of the recording, and thus looked forward to observing the 'authentic' performance during my visit. I did all the interviews and recorded the music in audio and video format and returned to the United States, where I later transcribed the performances. When I returned to Emure in May 2008 a prominent Emure female chief explained to me that new compositions should be composed for new and specific occasions. Although there is an underlining structural and melodic formula, and although certain key texts and phrases often recur, each song is unique, and every new performance is commemorated by a set of newly composed songs. I did not realize the full import of this information until much later when I paid another visit to the group as a whole. I had wanted them to perform the same songs so I could check to see if my transcriptions were correct. Although they remembered some of the songs, they explained that they would prefer to perform new and more recent songs rather than trying to figure out the texts of old songs. It was at this juncture that they began to put their heads together right in my presence to create 
new songs. Relying on past events as well as incorporating some pre-existing thematic material, they embarked on the process of generating new songs.

I watched them as they deliberated on their new compositions. They disagreed, agreed, rejected some phrases, argued strongly, adjusted phrases here and there, laughed, teased one another, and paused now and then as if confused, all in the process of working out a new performance. They told me that one of the songs they were putting together was derived from a previous performance of theirs that took place during the installation ceremony of their new king, an event held earlier in the year. After about forty five minutes of intense but well-mannered negotiation, they told me they were ready to perform a 'final version' for me. The social significance of this creative process is further explored below.

\section{Egbe and Asa: Musical Discourse as Social Action}

The notion of a musical discourse derives from the understanding that a musical activity often constitutes a social action. As Monson (2007:24) has explained, a musical discourse refers not just to 'talk about music', but also to 'the relationships between the sounds themselves and the symbolic, social, political, and personal meanings that individuals, collectivities, and institutions construct for them'. In olori and airegbe music, musical structures resonate with social significance both in terms of their positional relationships within the context of a performance as well as in terms of the creative actions from which they emanate. In the process of creating a new example of airegbe song, for example, Emure female chiefs employed two key words that describe the structural technique that guides their compositional process. These are egbe and esa. Egbe, as used by the women, refers to recurring key thematic elements of a performance, while esa refers to the process of structural unfolding that propels and gives full life to the performance. Emure women explained to me that egbe usually occurs right at the beginning of a song or performance, as an opening musical and textual material. It is the principal thematic idea, the germ from which an entire piece is built. On the other hand, esa is the 'flesh and body' of the piece. It is the part of the performance where the full details of the performance are worked out and negotiated. Egbe and esa are thus not mere musical materials: they constitute socio-musical activities. They refer to specific musical actions, which are enacted through negotiation, argument, debate, fun-poking, and even angry exchanges as I described above. The Yoruba word egbe literally means to support and to agree. It connotes communal harmony, both within the specific context of a musical performance as well as in terms of the social idea that generates or informs the performance. Within the specific context of 
performance, egbe serves the musical purpose of emphasis and as a symbol of agreement amongst the performers. Esa, like egbe, refers to a musical activity, while symbolizing a process of social interaction that informs the creation and defines the context of the performance. Esa, which translates as 'to choose', describes the process through which the opening egbe is developed into a full performance. Since the process of musical development could traverse an almost infinite pathway, the musical activity that esa describes is informed by an intense process of argumentation and bargaining leading to the adoption of a particular structural arrangement. The social conditions that the two words signify were clearly revealed in my earlier ethnographic description of the creative process employed by the women. The consequent emergence of the performance in its totality thus marks a state of agreement - a communal resolution, the process that led to the final agreement having been framed by intense debate, conflict and negotiation. It should also be noted that both egbe and esa have a dynamic character in the course of a performance. Within the context of a performance, egbe is constantly repeated, but also sometimes reworked. Esa, by its very nature is more dynamic since it involves a continuous process of extemporization and development. The final shape of the performance or composition is ultimately defined by the continuing dialectical engagement between egbe and esa.

\section{Conclusions}

The creative and performance conventions of olori and airegbe challenge certain assumptions about Yoruba performance. The attitude of the two female groups to the use of the drum is particularly significant in this regard. The drum, in its strong attachment to male musicians, has come to be regarded as an instrument through whose presence gender categories are inscribed into Yoruba musical practice. Its inclusion in traditional ensembles often invests men with considerable power. Emure women performers' attitude to the use of the drum serves to neutralize this power of the drum and the way in which its use might privilege the male gender. In the olori ensemble, women simply assume responsibility for the playing of the drum, ensuring that men are kept away from their ensemble. In airegbe music, the drum is prohibited altogether, foreclosing any potential basis for male participation. The dis-gendering of the drum in olori music and its neutralization in airegbe manifest the agency of a group of women who feel able to cope with the challenges that they face as women without the inclusion of the male gender. One might be tempted to interpret this process of identity construction through male exclusion as a deliberate oppositional move to curtail the power of men. The response that I kept getting from the women however contradicted any 
notion of oppositional gendering. Nonetheless, this dis-gendering and the neutralization of the drum, though not a strategic oppositional move, are both powerfully symbolic of the desire of these women to take control of their lives as they see it rather than as might be dictated to them by any other social category in the community. The structural features of airegbe music, the communal creative approach through which performers of the music work out new pieces, and the ways in which the boundaries of compositional styles are negotiated, varied and re-defined, are performance strategies that are agency-driven. Further, these performance and creative features underline the high level of professionalism that goes into the making of the music, and draws attention to the status of these women as an elite group with considerable cultural and political authority.

The role of the two female groups as the main musical groups within key festivals is significant both in their very presence at these festivals as well as in the content of their performances. It must be remembered that these two festivals constitute important public events at which the structures of power and the social and cultural values that help hold the Emure community together are renewed and consolidated. The strong presence of these all-female ensembles at these very important festivals draws attention to the status of Emure women as part of the political elite of their community. In addition, as highlighted in their songs, their performances, rather than fashioned as mere entertainment, constitute a critical part of the social conversation that takes places at these public events.

The status shift that is inherent in the progression from olori to airegbe, as displayed during the public performance that I described earlier, also has an equally strong social and political message. The acting-out, through the medium of musical performance, of the mobility between the two social categories of 'wife' and 'chief' helps to draw attention to the fluid nature of social movement among the women of Emure. Social mobility is dynamic, negotiable, and not encumbered by the factor of gender. Following the mobility inherent in the complementary relationship between olori and airegbe musical ensembles, the social status of Emure women, like that of their male counterparts, is shaped within an ongoing social process in which individual effort and seniority of age play vital roles. The fluctuating levels of identity that are homologically represented in the musical performance of chiefs (airegbe) and that of the king's wives (olori) offer a reflection on the shifting images of the power and status of Emure women. Emure community is organized in a manner that facilitates the elevation of women beyond the domestic space - the often powerless domain of a wife - into positions of social responsibility in the public sphere. 


\section{References}

Adegbite, A., 1988, ‘The Drum and its Role in Yoruba Religion', Journal of Religion in Africa, Vol. 18, Fasc. 1 (February):15-26.

Ampene, K., 2005, Female Song Tradition and the Akan of Ghana, Hampshire, England, and Burlington, VT USA: Ashgate Publishing Company.

Barber, K., 1990, 'Oriki, Women and the Proliferation and Merging of Orisha', Africa 60 (3): 313-335.

Drewal, M.T., 1992, Yoruba Ritual: Performers, Play and Agency, Bloomington and Indianapolis: Indiana University Press.

Euba, A., 1990, Yoruba Drumming: The Yoruba Tradition. Bayreuth: Bayreuth African Studies: 37-60.

Locke, D., 2005, 'Africa', Worlds of Music: An Introduction to the Music of the World's Peoples, ed., Titon, Jeff Todd, Belmont, CA: Schirmer (inc. CDs 1\& 2): 78-92.

Mack, B.B., 2004, Muslim Women Sing: Hausa Popular Song, Bloomington and Indianapolis: Indiana University Press.

Monson, I., 2007, Freedom Sounds: Civil Rights Call out to Jazz and Africa, New York: Oxford University Press.

Muller, C.A., 1999, Rituals of Fertility and the Sacrifice of Desire: Nazarite Women's Performance in South Africa, Chicago and London: University of Chicago Press.

Nannyonga-Tamusuza, S.A., 2005, Baakisimba: Gender in the Music and Dance of the Baganda People of Uganda, New York and London: Routledge. 
